\title{
Protection from emergencies, use of natural resources and system of economic loss evaluation in Russia
}

\author{
Alexander Rodionov ${ }^{1}$, Alexander Ovsianik ${ }^{1}$, Marina Danilina ${ }^{1,2,3}$, Mikhail Shahramanyan ${ }^{1}$, \\ and Peter Godlevskij ${ }^{1}$ \\ ${ }^{1}$ Financial University under the Government of the Russian Federation, Moscow, Russia \\ ${ }^{2}$ Plekhanov Russian University of Economics (PRUE), Moscow, Russia \\ ${ }^{3}$ Russian Research Institute (VNII) of Labor, Moscow, Russia
}

\begin{abstract}
In recent years, the world has experienced large-scale pollution and poisoning of environmental objects and the disappearance of certain parts of natural resources. The current research uses statistical data and methods in order to analyze the situation in the sphere of ecological and biological development on the basis of the main indicators. Among these indicators was chosen the current (operating) costs of environmental protection. The natural resource base of the Russian economy, the problems of which require immediate solutions, must be protected by the state. The country's environmental policy is aimed at creating appropriate conditions for reducing the anthropogenic impact on the environment to an acceptable level and restructuring this impact. Maintaining the lifesupporting systems of the biosphere, protecting and reproducing reserves are the primary actions that the natural resource base of the Russian economy requires. The problems facing today can be solved as follows: improving the regulatory system, developing the institution of state property, taking into account the division of competence between the state and the subjects, reforming and improving the system of economic assessment and accounting of natural resources, environmental restrictions, licensing the use of reserves, gradual changes in tax legislation, aimed at increasing the share of environmental payments while reducing rates for other fees, improving economic and financial mechanisms for the reproduction of reserves, developing the market for services and work in the field of environmental management.
\end{abstract}

\section{Introduction}

Natural resources form the basis of human civilization and its economic potential. All the materials necessary for production people get from the environment. Of course, the development of science and technology, changes in the economic sphere often dramatically change the direction, scale and forms of use of natural resources. At present, a fund of secondary materials created by labor has been formed. Nevertheless, natural resources are the primary source of material and energy potential. 
There is a huge amount of natural materials and raw materials on the territory of the country. It must be said that with the development of scientific and technological progress, their role in the development of society only increases. This is primarily due to the increasing needs of the population. To produce a sufficient quantity of products, an appropriate volume of raw materials is required. Therefore, more and more materials are being extracted from the environment. In the 17th century, the natural resource base of the Russian economy was formed mainly due to forests and arable land. By the 19th century, iron ore and coal had taken the lead.

Currently, one can observe an increase in the production of oil, non-ferrous metals and gas. Pristine landscapes suitable for recreation, rare reserves, nuclear raw materials, and fresh water are gaining increasing importance today. The natural resource base of the Russian economy requires a careful attitude towards itself. Natural reserves are limited. Maintaining the intensity of economic growth by increasing the use of natural resources is now almost exhausted. At present, the limitedness of land, forest and water resources has become more and more obvious.

A natural emergency is an unfavorable situation in a certain area resulting from a dangerous natural phenomenon that can lead to human casualties, damage to health, material losses and disruptions to the living conditions of the population. Emergency situations develop only when, as a result of the manifestation of a dangerous natural phenomenon, a real threat to human life and the environment arises. Natural emergencies are also called natural disasters. More than 20 types of dangerous hydrometeorological phenomena are encountered on the territory of Russia. These are strong winds, squalls, tornadoes, dust storms, showers and thunderstorms, hail, heavy continuous rains, droughts, frosts, snowfalls, blizzards, ice and frost phenomena, fogs, severe frosts, floods, avalanches, mudflows and others.

In recent years, the world has experienced large-scale pollution and poisoning of environmental objects and the disappearance of certain parts of natural resources. Industrial and domestic waste quickly accumulates, poisoning soil and water. Pesticides used in agriculture pollute groundwater sources, including drinking, and food.

The content of carbon dioxide and some other gases emitted into the atmosphere is increasing, in connection with this warming is already occurring in the upper layers of the near-earth space. Climate change is disrupting the conditions for agricultural production, as some areas will become more arid, while others - waterlogged. With the existing scale of carbon dioxide emissions into the atmosphere (without taking into account the increase in these emissions and without taking into account the loss of sources of oxygen generation), the temperature of the Earth's atmosphere will increase by two degrees in the next 25 years, and by seven degrees in 35 years. According to scientists, this can happen twice as fast.

This warming will cause intense melting of ice in the polar regions of the planet and, as a result, flooding of the most densely populated coastal regions. New York and London, Havana and Calcutta, St. Petersburg and Venice, Helsinki, Riga, and many other cities and capitals of the world can be under water. Today we are already feeling the signs of the greenhouse effect in the form of warm, snowless winters, more frequent showers and hurricanes. But warming threatens another disaster. If appropriate measures are not taken, then in the third millennium the increased mirror of the World Ocean will more intensely reflect the rays of the sun and absorb carbon dioxide (the atmosphere contains $0.03 \%$ carbon dioxide, in the ocean it is 60 times more), which can lead to a global cooling. and then to global glaciation, that is, a new ice age may begin.

The need to protect natural resources and environmental problems in Russia are the object of close attention from the state and scientists. On the territory of one of the largest states in the world, there are many unique natural complexes that are of great importance not only for the country, but for the entire planet. The environmental situation in Russia is 
threatened by the same factors that all states face, and they are associated with the expansion of civilized spaces, human use of the planet's resources, industrial development and pollution problems. The protection of natural resources should include a set of measures aimed at preserving renewable and non-renewable resources, environmentreproducing and resource-reproducing functions of nature.

\section{Materials and Methods}

The environmental problems most pressing for the country can be divided into the following groups:

- industrial pollution of air, soil, water;

-changing the natural landscape, deforestation;

-complex negative impact on the environment of large cities;

-Large volumes of incinerated and stored waste;

- consequences of man-made disasters.

Regarding all of the above factors, constant monitoring and supervision are carried out, measures are being developed to minimize harm to the environment. But the measures taken are not always enough to solve the problem completely.

The authors use content-analysis and statistical methods in order to execute the research of the current situation and produce the proposals.

Emergency situations are a whole complex of circumstances that have arisen in a particular territory as a result of a natural cataclysm, accident or disaster. An emergency situation is often characterized by a negative impact on the health and life of people, human casualties, significant material damage, and a destructive impact on nature. Among all types of natural emergencies, the greatest damage is caused by floods, hurricanes, typhoons, landslides, earthquakes, frosts, droughts and fires. Natural disaster statistics is presented in table 1 .

Table 1. Emergencies of natural character in the Russian Federation

\begin{tabular}{|c|c|c|c|c|c|c|}
\hline & \multicolumn{2}{|c|}{ Number of emergencies } & \multicolumn{2}{c|}{ Perished, people } & \multicolumn{2}{c|}{ Suffered, people } \\
\cline { 2 - 7 } & 2017 & 2018 & 2017 & 2018 & 2017 & 2018 \\
\hline $\begin{array}{c}\text { Heavy rains, snowfalls } \\
\text { and hail }\end{array}$ & 14 & 11 & 6 & 8 & 20468 & 1452 \\
\hline $\begin{array}{c}\text { Frosts, droughts } \\
\text { Hazardous hydrological } \\
\text { phenomena }\end{array}$ & 4 & 14 & - & - & - & - \\
\hline Large natural fire & 5 & 12 & 3 & - & 11756 & 52177 \\
\hline Total & 42 & 44 & 33 & 8 & 33964 & 53637 \\
\hline
\end{tabular}

Source: [1] Rosstat.

Cataclysms often lead to massive epidemics, epizootics and epiphytoties. The reason is a violation of the usual living conditions of people, animals and plants. Social disaster statistics is presented in table 2 . 
Table 2. Emergencies of social character in the Russian Federation

\begin{tabular}{|c|c|c|c|c|c|c|}
\hline & \multicolumn{2}{|c|}{ Number of emergencies } & \multicolumn{2}{c|}{ Perished, people } & \multicolumn{2}{c|}{ Suffered, people } \\
\cline { 2 - 7 } & 2017 & 2018 & 2017 & 2018 & 2017 & 2018 \\
\hline $\begin{array}{c}\text { Infectious diseases of } \\
\text { agricultural animals }\end{array}$ & 34 & 27 & - & - & - & - \\
\hline $\begin{array}{c}\text { Damage to agricultural } \\
\text { plants }\end{array}$ & 4 & 4 & - & - & - & - \\
\hline Total & 38 & 32 & - & - & - & 2 \\
\hline
\end{tabular}

Source: [1] Rosstat.

The rapidly spreading on the planet infection COVID-19 is a vivid example of a biological and social catastrophe of a global scale. It became the reason for the introduction of an emergency regime in many countries.

Man-made disasters are fraught with the release of biological, chemical and radioactive substances and the outbreak of fires at power plants or transport. Statistics of technogenic emergencies by years is presented in table 3 .

Table 3. Emergencies of natural character in the Russian Federation

\begin{tabular}{|c|c|c|c|c|c|c|}
\hline & \multicolumn{2}{|c|}{$\begin{array}{c}\text { Number of } \\
\text { emergencies }\end{array}$} & \multicolumn{2}{c|}{ Perished, people } & \multicolumn{2}{c|}{ Suffered, people } \\
\cline { 2 - 7 } & 2017 & 2018 & 2017 & 2018 & 2017 & 2018 \\
\hline $\begin{array}{c}\text { Freight and passenger } \\
\text { train accidents }\end{array}$ & 11 & 4 & 3 & - & 36 & - \\
\hline Plane crashes & 23 & 33 & 39 & 138 & 60 & 176 \\
\hline $\begin{array}{c}\text { Explosions in buildings } \\
\text { and structures of } \\
\text { residential, social and } \\
\text { cultural purpose }\end{array}$ & 18 & 16 & 24 & 129 & 689 & 361 \\
\hline $\begin{array}{c}\text { Collapse in buildings and } \\
\text { structures of residential, } \\
\text { social and cultural } \\
\text { purposes }\end{array}$ & 5 & 2 & 8 & 0 & 20 & 333 \\
\hline Total & 176 & 190 & 507 & 709 & 2335 & 3838 \\
\hline
\end{tabular}

Source: [1] Rosstat.

\subsection{Air and water pollution}

These problems of the natural resource base of the Russian economy are considered priority today. Air pollution is especially important in large settlements. In such cities, natural 
ventilation practically does not bring the desired effect. In addition, mobile and stationary sources of pollution have a negative impact. As for water bodies, their pollution is caused by the development of the industrial complex and urbanization. Available resources in the areas surrounding cities are often rapidly depleted or degraded so that the marginal costs of water supply increase several times. This is primarily due to the need to develop facilities at a considerable distance from settlements. In addition, a large amount of money is spent on cleaning and processing the incoming water due to its poor quality.

The problems of the natural resource base of the Russian economy affect other spheres of public life. Thus, the negative impact of polluted air leads to constant complaints from the population about obsessive, unpleasant odors, a statistically significant increase in morbidity and mortality. With regard to water, it is currently noted that about $50 \%$ of the population are forced to use raw materials that do not meet sanitary and hygienic requirements. More than $60 \%$ of coastlines are subject to erosion and flooding. This causes serious damage to the national economic complex and acts as an additional polluting source of the marine area.

\subsection{Noise pollution}

It has long been proven that such exposure causes significant harm to health. As the research results show, citizens living in the territory of acoustic discomfort are more likely than others to suffer from diseases of the central nervous system, cardiovascular system, sleep and breathing disorders. To correct this situation at the municipal and interdepartmental levels, it is necessary: to develop more advanced transport schemes, to carry out the construction of bypass roads, and to redistribute traffic flows. Expand highways, deepen, build protective screens. Conduct the construction of new houses as far as possible from city streets and major roads. Construction of buildings with noise protection, etc.

\subsection{Land degradation}

The natural resource base of the Russian economy and its assessment are of key importance for the development of agricultural production. The deterioration of the state of the land is being noted. Soil degradation is progressing at a rapid pace. It was found that the humus content decreased by $43 \%$ of the plowed areas. The balance sheet natural resource base of the economy in Russia is in an extremely tense state. In connection with the crisis in agriculture, the culture of farming is at a rather low level. No reduction in the areas exposed to radiation is observed.

The main problems of the natural resource base of the Russian economy arise from unwillingness to fulfill the requirements or improper fulfillment of them by economic entities. In $55 \%$ of the country's regions, compulsory land reclamation work is not carried out. For $30 \%$ of regions, this problem is assessed as a priority. These mainly include territories with a developed mining industry, northern regions, where the self-healing system practically does not work.

\subsection{Use of subsoil}

The state of the natural resource base of the Russian economy, the problems and prospects for the development of the production sector are relevant for all economic entities. They are especially important for enterprises in the mining and processing industries. Mining operations have a negative impact on the environment. This influence is increasing due to the difficult situation of many mining enterprises, the lack of an effective 
program for the use and protection of subsoil. The natural resource basis of the Russian economy, the problems and prospects of its further exploitation should be regulated by regulatory documents. However, there are many shortcomings and gaps in them. This further aggravates the current situation. The urgency of the issue on the integrated use of mineral raw materials is not diminishing. The emergency resistance of hazardous objects of the ore industry is at a rather low level today. The problems of the natural resource base of the economy are in many cases provoked by the obsolescence of technological equipment, technologies and methods of extraction and processing.

\subsection{Animals, forest, plants}

They form a renewable natural resource base of the economy. However, as a result of largescale human activities, this part of natural reserves is actively degrading. Forest fires cause significant damage. In some territories, the intensity of desertification processes does not decrease. The problem of preserving the animal world, including fish resources, is considered a priority today. Its solution is related to the protection, supervision, regulation of the use of natural habitats.

\subsection{Radiation contamination}

It can relate to water bodies, surface air, terrain. Radiation contamination causes serious problems for the natural resource base of the economy. They are mainly caused by: Lack of reliable technologies and methods of waste storage. Slow rates of modernization at nuclear power facilities, untimely replacement of items of equipment that have reached their end of life, insufficient safety level during the repair of installations. Accumulation at industrial enterprises and medical institutions of products with radiation protection from depleted uranium, subject to replacement or not being used.

\subsection{Environmental protection in the Russian Federation}

The current research uses statistical data and methods in order to analyze the situation in the sphere of ecological and biological development on the basis of the main indicators. Among these indicators was chosen the current (operating) costs of environmental protection.

At the moment, the current (operating) costs of environmental protection are not at the proper level. This creates problems for the ecological and biological development of the country. The detailed analysis of the current (operating) costs of environmental protection in the Russian Federation on 24.04.2020 (table 4) shows that amount of costs constantly grew in almost all types of costs except for research and development activities to reduce negative anthropogenic impacts on the environment where the amount of costs started to diminish from 2013. The total amount of current (operating) costs of environmental protection in 2019 reached 374411 million rubles. 
Table 4. Current (operating) costs of environmental protection in the Russian Federation on 24.04.2020 (at actual prices; million rubles).

\begin{tabular}{|c|c|c|c|c|c|c|c|c|c|c|}
\hline & & \multicolumn{9}{|c|}{ Including: } \\
\hline & $\begin{array}{l}\text { To } \\
\text { tal }\end{array}$ & $\begin{array}{l}\text { pro- } \\
\text { tec- } \\
\text { tion of } \\
\text { at } \\
\text { mos- } \\
\text { phe- } \\
\text { ric air } \\
\text { and pre- } \\
\text { ven- } \\
\text { tion of } \\
\text { cli } \\
\text { mate } \\
\text { chan- } \\
\text { ge }\end{array}$ & $\begin{array}{c}\text { for } \\
\text { collec- } \\
\text { tion } \\
\text { and } \\
\text { treat- } \\
\text { ment of } \\
\text { waste } \\
\text { water }\end{array}$ & $\begin{array}{c}\text { for } \\
\text { waste } \\
\text { mana- } \\
\text { gement }\end{array}$ & $\begin{array}{c}\text { for the } \\
\text { protect- } \\
\text { tion } \\
\text { and } \\
\text { reha- } \\
\text { bili- } \\
\text { tation } \\
\text { of land, } \\
\text { surface } \\
\text { and } \\
\text { ground } \\
\text { waters }\end{array}$ & $\begin{array}{l}\text { to pro- } \\
\text { tect } \\
\text { the } \\
\text { envi- } \\
\text { ron- } \\
\text { ment } \\
\text { from } \\
\text { noise, } \\
\text { vibra- } \\
\text { tion } \\
\text { and } \\
\text { other } \\
\text { types } \\
\text { of } \\
\text { phy- } \\
\text { sical } \\
\text { impact }\end{array}$ & $\begin{array}{l}\text { to } \\
\text { pre- } \\
\text { serv } \\
\text { e } \\
\text { bio- } \\
\text { di- } \\
\text { ver- } \\
\text { sity } \\
\text { and } \\
\text { pro- } \\
\text { tect } \\
\text { na- } \\
\text { tural } \\
\text { area } \\
\text { s }\end{array}$ & $\begin{array}{l}\text { to en- } \\
\text { sure } \\
\text { radia- } \\
\text { tion } \\
\text { sa- } \\
\text { fety of } \\
\text { the } \\
\text { envi- } \\
\text { ron- } \\
\text { ment }\end{array}$ & $\begin{array}{c}\text { for re- } \\
\text { search } \\
\text { and } \\
\text { deve- } \\
\text { lop- } \\
\text { ment } \\
\text { active- } \\
\text { ties to } \\
\text { reduce } \\
\text { nega- } \\
\text { tive } \\
\text { anthro- } \\
\text { pogenic } \\
\text { impacts } \\
\text { on the } \\
\text { envi- } \\
\text { ron- } \\
\text { ment }\end{array}$ & $\begin{array}{c}\text { to } \\
\text { other } \\
\text { areas } \\
\text { of } \\
\text { acti- } \\
\text { vity } \\
\text { in the } \\
\text { field } \\
\text { of } \\
\text { envi- } \\
\text { ron- } \\
\text { ment } \\
\text { al } \\
\text { pro- } \\
\text { tect- } \\
\text { tion }\end{array}$ \\
\hline$\frac{\sim}{\stackrel{\sim}{\sim}}$ & 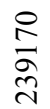 & 47062 & 121332 & 45798 & 13701 & 262 & 534 & 4795 & 460 & 5225 \\
\hline$\frac{m}{\stackrel{n}{d}}$ & \begin{tabular}{l}
$\stackrel{N}{n}$ \\
\multirow{2}{n}{} \\
$\stackrel{2}{v}$
\end{tabular} & 44800 & 132818 & 50402 & 15337 & 273 & 314 & 5342 & 1022 & 4069 \\
\hline$\underset{\sim}{\stackrel{\Delta}{d}}$ & 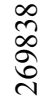 & 50920 & 136468 & 55702 & 15266 & 308 & 350 & 6088 & 937 & 3799 \\
\hline$\frac{n}{\stackrel{n}{d}}$ & 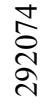 & 58250 & 145147 & 60256 & 16660 & 289 & 336 & 5459 & 582 & 5096 \\
\hline 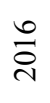 & 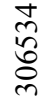 & 56851 & 154313 & 63580 & 19526 & 357 & 396 & 5843 & 647 & 5022 \\
\hline$\stackrel{\bar{c}}{\sim}$ & 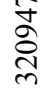 & 56906 & 163261 & 70041 & 15452 & 289 & 422 & 6328 & 464 & 7783 \\
\hline$\frac{\infty}{\stackrel{d}{i}}$ & 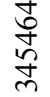 & 61075 & 173688 & 79885 & 15347 & 381 & 514 & 7728 & 205 & 6641 \\
\hline$\stackrel{\partial}{\stackrel{\sim}{~}}$ & 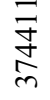 & 63760 & 174921 & 102396 & 16348 & 354 & 639 & 8266 & 219 & 7506 \\
\hline
\end{tabular}

Source: [1] Rosstat. 


\section{Results}

The natural resource base of the Russian economy, the problems of which require immediate solutions, must be protected by the state. The country's environmental policy is aimed at creating appropriate conditions for reducing the anthropogenic impact on the environment to an acceptable level and restructuring this impact. Maintaining the lifesupporting systems of the biosphere, protecting and reproducing reserves are the primary actions that the natural resource base of the Russian economy requires. The problems facing today can be solved as follows: Improving the regulatory system. This includes a reasonable delineation of powers of federal, local, regional executive structures.

Development of the institution of state property, taking into account the division of competence between the state and the subjects. Reforming and improving the system of economic assessment and accounting of natural resources, environmental restrictions, licensing of the use of reserves.

A gradual change in tax legislation aimed at increasing the share of environmental payments while reducing rates on other fees.

Improvement of economic and financial mechanisms for the reproduction of reserves, development of the market for services and work in the field of environmental management.

\section{Discussion}

As we found out, the protection of the natural resources in Russia need urgent measures. The use and protection of natural resources in Russia involves the implementation of certain measures to restore and improve them.

Article 23 of the Law of the Russian Federation "On Subsoil" dated February 21, 1992 states that the main areas of rational use of subsoil are:

complete extraction of minerals from them, both basic and jointly occurring;

a progressive method of geological study of the subsoil for a correct assessment of the availability of minerals, their quantitative and qualitative composition, as well as for studying the features of territories not intended for mining.

Subsoil protection includes activities, the main of which are:

-protection from fires, watering, flooding and other negative factors of minerals;

-protection of valuable deposits from a decrease in the quality of extracted resources or from complications in their processing;

-prevention of pollution during work on the use of subsoil.

Article 1 of the Water Code of the Russian Federation states that the protection of water bodies is the activity aimed at their preservation and restoration. The main need, which is indicated by article 11 of the same code, is prevention and maximum elimination of possible negative consequences of the use of water bodies. Ignoring this need leads to legal consequences.

The Forest Code of the Russian Federation in article 2 establishes the provision of rational use of forest resources, their protection and reproduction as the main direction of legal activity of forest legislation. The main activities for the protection of forests:

forestry operations in ways that limit the negative impact on the territories used;

application of forest restoration measures;

cleaning of cutting areas.

The protection of objects of the animal world is defined by the Federal Law "On the animal world" of April 24, 1995 as activities aimed at the stable existence of the animal world and the preservation of the animal gene pool, associated with the creation of legal conditions for the use of objects of the animal world without negative consequences. 
Land protection, according to Article 12 of the Land Code of the Russian Federation, pursues the following goals:

prevention of degradation, littering, disturbance and pollution of land under the influence of human economic activity;

restoration and improvement of lands affected by the negative impact of human activity.

According to Article 1 of the Federal Law "On the Protection of Atmospheric Air", the protection of atmospheric air is a set of measures to improve the properties of atmospheric air in order to prevent its harmful effects on the environment.

Summarizing the provisions of environmental legislation on the protection and use of the environment, we can conclude that measures for the protection of natural resources are aimed at preserving and improving the species, qualitative and quantitative characteristics of renewable and non-renewable natural resources and preventing harm to them.

The website of the Ministry of Natural Resources and Environment of Russia contains the state program of the Russian Federation "Environmental Protection" for 2012-2020. Among the goals of the program are to reduce the anthropogenic load on the environment by an average of two times, improve the ecological quality of life of Russians, restore and preserve biodiversity in the country, as well as organize and increase the efficiency of scientific work in related areas.

The main goal of the state program is to increase the level of environmental safety and preserve the biodiversity of the natural systems of the Russian Federation. The document is intended to become the basis for solving key environmental problems; it links into a single system and measures of legal regulation aimed at economic stimulation of environmentally oriented "green growth", and practical measures to improve the state of the environment.

The program includes five subprograms: "Environmental quality regulation", "Biological diversity of Russia", "Hydrometeorology and environmental monitoring", "Organization and support of work and scientific research in Antarctica", "Ensuring the implementation of the state program of the Russian Federation" Environmental protection "For 2012-2020", as well as the federal target program "Protection of Lake Baikal and socio-economic development of the Baikal natural territory for 2012-2020". Total funding for the program in 2012-2020 at the expense of the federal budget is 268.4 billion rubles.

During the implementation of the program, the following results are expected to be obtained in quantitative terms (compared to the base year 2007): a decrease in the volume of emissions of harmful (pollutants) substances from stationary sources per unit of GDP by 2.2 times, a decrease in the volume of waste of all hazard classes per unit of GDP - 1.6 times. It is also planned to reduce the number of cities with high and very high levels of pollution (pollution index more than 7) of atmospheric air by 2.7 times, to improve environmental conditions for 36.1 million Russians currently living in such cities.

The share of the Russian Federation's area occupied by specially protected natural areas of all levels will increase to $13.5 \%$ of the country's territory. The responsible executor of the program is the Russian Ministry of Natural Resources. The program participants are Rosprirodnadzor, Roshydromet, Rosvodresursy, Rosnedra, Ministry of Industry and Trade of Russia, Ministry of Regional Development of Russia, Federal Agency for Fishery.

The plan of activities of the Ministry of Natural Resources and Environment of the Russian Federation for 2019 - 2024 sets the following goals:

1. Creation of conditions for the formation of a favorable environment;

2. Ensuring the protection of the population and objects of vital activity from the impact of dangerous natural phenomena;

3. Ensuring the international legal registration of the external borders of the Russian Federation, including the external border of the continental shelf;

4. Guaranteed provision of natural resources for sustainable social and economic development of the Russian Federation; 
5. Formation of a highly efficient hydrometeorological service;

6. Realization of the national interests of the Russian Federation in Antarctica;

7. Implementation of the national project "Ecology".

To achieve the set goals, it is necessary to ensure the solution of the following tasks:

- preparation of regulations in order to implement the Federal Law of July 21, 2014 No. 219-FZ "On Amendments to the Federal Law" On Environmental Protection "and Certain Legislative Acts of the Russian Federation";

- the formation of an integrated system for the management of solid municipal waste, including the elimination of landfills and the reclamation of the territories on which they are located, the creation of conditions for the recycling of all production and consumption waste prohibited for burial;

-creation and effective functioning in all constituent entities of the Russian Federation of a system of public control aimed at identifying and eliminating unauthorized dumps;

- creation of modern infrastructure to ensure the safe handling of waste of I and II hazard classes, and the elimination of the most dangerous objects of accumulated environmental damage;

-implementation of comprehensive plans of measures to reduce emissions of pollutants into the air in large industrial centers, including the cities of Bratsk, Krasnoyarsk, Lipetsk, Magnitogorsk, Mednogorsk, Nizhny Tagil, Novokuznetsk, Norilsk, Omsk, Chelyabinsk, Cherepovets and Chita, taking into account the consolidated calculations of the permissible negative impact on the environment in these cities;

-Application by all objects that have a significant negative impact on the environment, an environmental regulation system based on the use of the best available technologies;

- improving the quality of drinking water by modernizing water supply systems using advanced water treatment technologies, including technologies developed by organizations of the military-industrial complex;

-ecological rehabilitation of water bodies, sustainable functioning of the water management complex of the Lower Volga and preservation of the ecosystem of the Volga-Akhtuba floodplain;

- preservation of unique water bodies, including the implementation of a project to preserve Lake Baikal, as well as measures to clean up the shores and coastal waters of lakes Baikal, Teletskoye, Ladoga, Onega and the rivers Volga, Don, Ob, Yenisei, Amur, Ural, Pechora ;

-conservation of biological diversity, including an increase in the area of specially protected natural areas by 5 million hectares, the reintroduction of rare species of animals, the creation of infrastructure for ecological tourism in national parks, an increase in the number of visitors to specially protected natural areas;

-preservation of forests, including on the basis of their reproduction in all areas of felled and dead forest stands.

Rational use of water resources is one of the main problems, the solution of which lies in the following processes:

-the use of one-stage production processes instead of multi-stage;

-transition from liquid to gas processing processes;

-replacement of industrial water with other solvents;

-extraction of useful substances from wastewater;

-transfer of industrial enterprises to waste-free production technology;

-transition to complex processing of raw materials. 


\section{Conclusions}

The lack of a unified methodology for assessing the economic consequences of emergency situations leads to the fact that in practice, when assessing economic damage, only direct losses of material values are taken into account. As a result, the state, subjects of the federation, municipal formations and economic objects, being exposed to one or another emergency, experience an acute shortage of all types of resources to eliminate the emergency itself and restore normal life. The system for assessing the economic damage of large-scale emergencies should include:

- rational distribution of productive forces and settlements from the point of view of their natural and man-made safety;

- preparation of objects of the economy and systems of life support of the population for sustainable functioning in emergency situations;

- renewal of fixed assets;

- declaration of industrial safety;

- licensing of activities in the field of industrial safety;

- state expertise in the field of protection of the population and territories from emergencies;

- state supervision and control in the field of protection of the population and territories from emergencies.

The natural resource base of the Russian economy, the problems of which are becoming more and more extensive every year, requires close attention not only from the state, but also from the society itself. For the improvement of the air, for example, target programs, projects for the reconstruction and reorganization of hazardous industries are being developed at the federal level. Scientific work is underway, new units are being created, new methods of water purification are being developed. To solve the existing problems of the natural resource base of the Russian economy, it is necessary to strictly comply with the established requirements and standards. It depends on the users themselves, consumers. At the state and regional levels, control services have been formed that ensure the verification of the fulfillment of instructions.

\section{References}

1. Rosstat, official site, (2020) www.rosstat.gov.ru

2. Law of the Russian Federation "On Subsoil" dated February 21, (1992)

3. Water Code of the Russian Federation

4. Forest Code of the Russian Federation

5. Federal Law "On Animal World" dated April 24, (1995)

6. Land Code of the Russian Federation

7. Federal law "On the protection of atmospheric air"

8. State Program of the Russian Federation "Environmental Protection" for 2012-2020

9. Action plan of the Ministry of Natural Resources and Environment of the Russian Federation for 2019 - 2024 